\title{
HCV and HEV: two players in an Egyptian village, a study of prevalence, incidence, and co-infection
}

\author{
Mohammed Elhendawy ${ }^{1} \cdot$ Lobna Abo-Ali $^{1}$ - Sherief Abd-Elsalam ${ }^{1}$ (D) Maha M. Hagras $^{2} \cdot$ Ibrahim Kabbash $^{3}$. \\ Loai Mansour $^{1}$. Sherief Atia ${ }^{4}$. Gamal Esmat ${ }^{5}$. Abdel-Raouf Abo-ElAzm ${ }^{1} \cdot$ Ferial El-Kalla $^{1} \cdot$ Abdelrahman Kobtan $^{1}$
}

Received: 7 March 2020 / Accepted: 1 June 2020 / Published online: 12 June 2020

(C) Springer-Verlag GmbH Germany, part of Springer Nature 2020

\begin{abstract}
The highest recorded hepatitis C virus (HCV) prevalence worldwide is in Egypt. A high prevalence of hepatitis E virus (HEV) in chronic liver disease has been reported. The aim of this study was to study prevalence, incidence, and outcome of HCV infection in an Egyptian Nile Delta village and the relation between HEV infection and HCV-related chronic hepatic affection. This prospective cohort study included 2085 Nagreej village residents. Mass HCV screening was conducted and testing for HEV antibodies among HCV-infected patients performed. The annual incidence of HCV was recorded. Five hundred five (24.22\%) of the tested villagers were positive for HCV RNA. Prevalence escalated with age and male sex. The main recorded risk factors were a history of surgery, dental procedures, hospitalization, blood transfusion, and antischistosomal treatment. HEV IgG antibody was positive in $71.4 \%$ of individuals with chronic HCV and $96.1 \%$ with advanced liver disease (cirrhosis \pm hepatocellular carcinoma (HCC)). After 1 year, 29 of the $1390 \mathrm{HCV}$ Ab negative villagers had a positive HCV PCR, placing an annual incidence of new HCV infections at 2.09\%. The Egyptian HCV prevalence remains high with infection particularly among the elderly. The annual incidence in a small Nile Delta village is $2.086 \%$. HCV-HEV co-infection may lead to a worse prognosis among Egyptians with chronic liver disease.
\end{abstract}

Keywords $\mathrm{HCV} \cdot \mathrm{HEV} \cdot$ Egypt $\cdot$ Epidemiology $\cdot$ Prevalence $\cdot$ Chronic liver disease

\section{Introduction}

Estimates for the very high prevalence in Egypt are based on data from the Egypt Demographic and Health Survey (EDHS)

Responsible Editor: Lotfi Aleya

Electronic supplementary material The online version of this article (https://doi.org/10.1007/s11356-020-09591-6) contains supplementary material, which is available to authorized users.

Sherief Abd-Elsalam

Sherif_tropical@yahoo.com

1 Tropical Medicine Department, Faculty of Medicine, Tanta University Hospital, Tanta University, El Geish Street,

Tanta, Gharbia Governorate, Egypt

2 Clinical Pathology Department, Tanta University, Tanta, Egypt

3 Public Health and Community Medicine, Tanta University, Tanta, Egypt

4 Kafr El Sheikh Liver Institute, Kafr El Sheikh, Egypt

5 Tropical Medicine Department, Cairo University, Cairo, Egypt in 2008 that recorded $14.7 \%$ anti-HCV prevalence and $9.8 \%$ active HCV infection among individuals aged 15-59 years (El-Zanaty and Way 2009).

In 2015, another survey was performed and a decline in $\mathrm{HCV}$ prevalence in Egypt was recorded in the same age group. The estimated prevalence of $\mathrm{HCV}$ antibody positivity was $10 \%$ and for active infection was $7.0 \%$ (Ahmed et al. 2018).

The prevalence of active HCV infection in Egypt varies according to the area, being the highest in Menoufia at $8 \%$. Other governorates with a rate of $\geq 5 \%$ included Sharkia, Menya, Gharbia, Dakhalia, Behera, Damietta, Fayoum, and Beni Suef according to the 2015 survey (Egypt Health Issues Survey 2015).

Widespread Egyptian campaigns in the 1960s and 1970s aiming at eradication of schistosomiasis by parenteral treatment resulted in high levels of HCV transmission via contaminated needles and a higher prevalence of HCV than in other countries (Frank et al. 2000). Other risk factors in Egypt are male sex, old age, blood transfusion, hemodialysis, and residence in the Nile Delta region (Strickland et al. 2002). 
Infection with hepatitis $\mathrm{E}$ virus (HEV) is a worldwide problem with a global burden estimated in 2005 at 20 million infections, causing 70,000 deaths per year (Rein et al. 2012).

The incidence and sequelae of HEV infection on top of chronic HCV infection are unclear. There have been reports of decompensation of pre-existing cirrhosis, and heightened morbidity and mortality among chronic hepatitis $\mathrm{C}$ affected individuals (Ramachandran et al. 2004).

This work aimed to study the prevalence, incidence, and outcome of HCV infection in an Egyptian Nile Delta village and the relation between HEV infection and HCV-induced chronic hepatic affection.

\section{Methods}

\section{Study design}

This is a prospective cohort study recording the prevalence of hepatitis $\mathrm{C}$ infection and its outcome in a small village in the Nile Delta of Egypt. Mass HCV screening was conducted with further testing of $\mathrm{HCV}$-infected villagers for $\mathrm{HEV}$ antibodies.

The incidence of $\mathrm{HCV}$ infection after 1 year was detected by repeat antibody testing for those previously negative. Confirmation of the incident infection was performed by HCV RNA PCR testing to estimate the actual infection incidence. Therefore, the incidence of new infections was dependent on the detection of viral RNA.

\section{Study settings}

This study was conducted on the residents of the small rural village of Nagreej, Basyoun, Gharbia Governorate, with a population around 8000 at the time of the study, of whom those aged $18-60$ years were about 3600 . Survey and prevalence were estimated from the beginning of July 2015 until the end of March 2016. Follow-up of HCV negative subjects was performed from mid-March 2017 until the end of October 2017.

\section{Study subjects}

The sample size of this study was 2085 persons aged 18 60 years, present at the village during the study period and willing to take part in the study.

\section{Exclusion criteria}

This study included resident villagers younger than 18 or older than 60 years and those who refused to participate.

\section{Methods of data collection}

This study was conducted through weekly visits to the village following the Friday prayers. The village inhabitants were informed about the study by means of an advertising campaign carried out by local volunteers. Villagers were invited to attend at the local headquarters of a non-governmental charity organization. The number of villagers interviewed was between 70 and100 weekly. A data collection sheet was designed to register the data of all participants.

\section{Serum sample collection}

Serum: Blood was drawn using standard venipuncture techniques; the serum was extracted, then removed and divided into aliquots, and stored at $-20{ }^{\circ} \mathrm{C}$.

\section{Detection of viral infection}

$\mathrm{HCV}$ antibody was determined by an enzyme-linked immunosorbent assay (ELISA) kit (catalog no. MBS702189, My BioSource, Inc., UK).

Quantitative measurement of the serum load of $\mathrm{HCV}$ was performed by real-time PCR (Cobas Ampliprep/Taqman HCV Monitor version 2.0; Roche Diagnostic Systems, Pleasanton, California, USA), by following the manufacturer's instructions. The limit for detection was $15 \mathrm{IU} / \mathrm{ml}$ (https://diagnostics.roche.com/global/en/products/params/ cobas-ampliprep-cobas-taqman-hcv-test-v2-0-qualitativeand-quantitative.html).

The COBAS AmpliPrep/COBAS TaqMan HCV Test allows automated specimen preparation followed by automated reverse transcription, PCR amplification, and detection of both HCV target RNA and HCV Quantitation Standard (QS) Armored RNA. The Master Mix reagent contains primers and probes specific for both HCV RNA and HCV QS Armored RNA. Detection of amplified DNA is performed using a target-specific and a QS-specific dual-labeled oligonucleotide probe which permit independent identification of both $\mathrm{HCV}$ and HCV QS amplicons. The COBAS TaqMan Analyzer calculates the HCV RNA concentration in the test specimens by comparing the HCV signal to the HCV QS signal for each specimen and control (Deeks 2015).

HEV antibody (IgG) was measured by the ELISA kit (catalog no. NBP2 60048, Novus Biological, a Bio-Techne brand, USA). HEV antibody IgM was measured by the ELISA technique kit (catalog no. KA1009, Abnova, Taiwan).

By following the manufacturer's instructions, sandwich enzyme immunoassay was used for the quantitative measurement of HCV- and HEV-specific antibodies using these colorimetric ELISA kits which have high sensitivity and excellent specificity for detection of human HCV and HEV 
antibodies with no significant cross-reactivity or interference between these antibodies and analogues.

All subjects were interviewed and asked about sociodemographic data, history of chronic disease, surgery, invasive procedures, dental procedures, parenteral antischistosomal treatment, blood or blood product transfusions, and transplants.

For all participants with a confirmed HCV infection, a full clinical examination and Child-Pugh staging of liver disease were performed as well as laboratory investigations including complete blood count, liver function tests, prothrombin time (sec) and activity (\%), urea and creatinine, alpha fetoprotein (AFP), anti-HEV IgG and IgM, and pelvi-abdominal ultrasonography. The HCV antibody negative population was retested a year later to estimate the incidence of new $\mathrm{HCV}$ infections.

\section{Statistical analysis}

The collected data were organized, tabulated, and analyzed using SPSS version 19 (IBM, Chicago, Illinois, USA). Quantitative data were presented as mean and standard deviation, while qualitative data were presented as frequency and percentage. Comparisons of mean values between groups were done using the Student $\mathrm{s} t$-test. To compare categorical data, the chi-square test was performed. Multivariate logistic analysis was carried out using a logistic regression model to identify risk factors of HCV infection. The level of significance applied was $p<0.05$.

\section{Results}

\section{Prevalence of hepatitis C virus infection}

Out of the 3600 villagers aged 18-60 years old, 2085 were tested for hepatitis $\mathrm{C}$ infection. Antibodies to $\mathrm{HCV}$ were positive for 542 villagers. Confirmatory PCR for HCV RNA was performed for all antibody positive participants revealing that $37 / 542$ had anti-HCV antibodies but without detectable HCV RNA. Active infection was recorded for 505 villagers.

$\mathrm{HCV}$ infection was found to increase significantly with the progression of age $(p=0.001)$. The mean age in the hepatitis $\mathrm{C}$ antibody negative group $(36.69+12.14)$ was lower compared with the hepatitis $C$ infected group $(45.68+9.55)(p=$ 0.001 ). The lowest prevalence was among those younger than $20(1.9 \%)$, and the highest was $40.2 \%$ in the $50-59$ years group (Table 1). A higher prevalence was noted among males $(30.3 \%)$ than females $(19.9 \%)(p<0.001)$ (Table 2$)$.

As regards the distribution of $\mathrm{HCV}$ cases in relation to occupation, $47.6 \%$ were housewives, $26.8 \%$ manual laborers, $16.7 \%$ farmers, $8.3 \%$ government employees, and $0.6 \%$ students.
Table 1 Comparison of age in relation to hepatitis $\mathrm{C}$ infection

\begin{tabular}{llllll}
\hline & \multicolumn{3}{l}{ Hepatitis C infection } & & \\
\cline { 2 - 3 } Age in years & \multicolumn{2}{l}{ Negative $(n=1543)$} & & \multicolumn{2}{l}{ Positive $(n=505)$} \\
\cline { 2 - 3 } \cline { 5 - 6 } & $n$ & & & $n(\mathrm{M} / \mathrm{F})$ & $\%$ \\
\hline $18-<20$ & 103 & 98.1 & & $2(2 / 0)$ & 1.9 \\
$20-29$ & 378 & 94.7 & & $21(15 / 6)$ & 5.3 \\
$30-39$ & 469 & 83.9 & & $90(42 / 48)$ & 16.1 \\
$40-49$ & 290 & 60.7 & & $188(113 / 75)$ & 39.3 \\
$50-59$ & 303 & 59.8 & & $204(110 / 94)$ & 40.2 \\
Mean \pm SD & $36.69 \pm 12.14^{\mathrm{a}}$ & & $45.68 \pm 9.55$ & \\
$p$ Value & ${ }^{\mathrm{a}} \mathrm{p}=0.001 * \$$ & $p=0.078^{\#}$ & & \\
\hline
\end{tabular}

${ }^{\$}$ Independent Student's $t$-test, ${ }^{*} \chi^{2}$ test; M/F, male/female; ${ }^{a} \mathrm{p}$, when compared with hepatitis $\mathrm{C}$ infected patients; $\mathrm{p}$, when compared the gender with regard to different age groups in hepatitis $\mathrm{C}$ infected patients, *statistically significant at $p<0.05$

A relation between the history of medical care and the acquirement of hepatitis $\mathrm{C}$ infection was evident as it was found that previous hospital admission, surgical operations, dental procedures, blood transfusion, and history of receiving parenteral antischistosomal therapy were significantly higher in HCV positive villagers $(p=0.036,<0.001,<0.001,0.042$, 0.004 , respectively) (Table 3 ). On the other hand, no significant difference as regards the use of shared or contaminated needles, tattooing, or drug abuse was noted (Table 3 ).

The occurrence of diabetes and cardiac diseases but not hypertension was significantly higher in $\mathrm{HCV}$ positive individuals.

Multivariate regression analysis to estimate risk factors of infection was carried out and revealed: Age, male gender, chronic diseases, DM, and dental procedures were significantly higher in HCV positive individuals (Table 4).

Laboratory investigations and abdominal ultrasound scans performed for all 505 villagers with an active $\mathrm{HCV}$ infection revealed that 204 were suffering from advanced liver disease (201 cirrhosis and 3 HCC), while 301 had chronic hepatitis C. The villagers with advanced liver disease were significantly

Table 2 Hepatitis C infection in relation to gender

\begin{tabular}{|c|c|c|c|c|c|}
\hline \multirow{3}{*}{ Gender } & \multicolumn{4}{|c|}{ Hepatitis C infection } & \multirow{3}{*}{$p$ Value } \\
\hline & \multicolumn{2}{|c|}{ Negative $(n=1543)$} & \multicolumn{2}{|c|}{ Positive $(n=505)$} & \\
\hline & $n$ & $\%$ & $n$ & $\%$ & \\
\hline Male & 648 & 69.7 & 282 & 30.3 & \\
\hline Female & 895 & 80.1 & 223 & 19.9 & $<0.001 *$ \\
\hline
\end{tabular}

$\chi^{2}$ test, * statistically significant at $p<0.05$ 
Table 3 Risk factors for hepatitis $\mathrm{C}$ infection in relation to medical history

\begin{tabular}{|c|c|c|c|c|c|}
\hline \multirow{3}{*}{ Medical history } & \multicolumn{4}{|c|}{ Hepatitis C infection } & \multirow{3}{*}{$p$ Value } \\
\hline & \multicolumn{2}{|c|}{ Negative $(n=1543)$} & \multicolumn{2}{|c|}{ Positive $(n=505)$} & \\
\hline & $n$ & $\%$ & $n(\mathrm{M} / \mathrm{F})$ & $\%$ & \\
\hline \multicolumn{5}{|c|}{ Hospital admission } & \multirow{3}{*}{$0.036^{*}$} \\
\hline Negative & 1413 & 76.1 & 443 & 23.9 & \\
\hline Positive & 130 & 67.7 & $62(35 / 27)$ & 32.3 & \\
\hline \multicolumn{5}{|l|}{ Surgical history } & \multirow[t]{3}{*}{$<0.001 *$} \\
\hline Negative & 986 & 78.6 & 268 & 21.4 & \\
\hline Positive & 557 & 70.2 & $237(100 / 137)$ & 29.8 & \\
\hline \multicolumn{5}{|l|}{ Dental procedures } & \multirow[t]{3}{*}{$<0.001^{*}$} \\
\hline Negative & 1203 & 79.5 & 311 & 20.5 & \\
\hline Positive & 340 & 63.7 & $194(93 / 101)$ & 36.3 & \\
\hline \multicolumn{5}{|l|}{ Blood transfusion } & \multirow[t]{3}{*}{$0.042 *$} \\
\hline Negative & 1417 & 76.1 & 445 & 23.9 & \\
\hline Positive & 126 & 67.7 & $60(44 / 16)$ & 32.3 & \\
\hline \multicolumn{5}{|c|}{ Contaminated needles, tattooing, and drug abuse } & \multirow[t]{3}{*}{0.535} \\
\hline Negative & 1539 & 75.4 & 502 & 24.6 & \\
\hline Positive & 4 & 57.1 & $3(2 / 1)$ & 42.9 & \\
\hline \multicolumn{5}{|c|}{ Receiving parenteral antischistosomal therapy } & \multirow[t]{3}{*}{$0.004 *$} \\
\hline Negative & 1476 & 76.1 & 464 & 23.9 & \\
\hline Positive & 67 & 62.04 & $41(32 / 9)$ & 37.96 & \\
\hline
\end{tabular}

$\chi^{2}$ test; M/F, male/female; *statistically significant at $p<0.05$

older (mean age $56.21 \pm 8.36$ years) than those with chronic hepatitis $(43.80 \pm 9.53$ years $)(p<0.001 *)$ (Table 5$)$.

All villagers proven to have a positive HCV RNA were treated at their regional ministry of health center for control of viral hepatitis.

Table 4 Multivariate regression analysis

\begin{tabular}{lllll}
\hline & Odds ratio & \multicolumn{3}{l}{$95.0 \%$ CI for EXP (B) } \\
\cline { 3 - 5 } & & Lower & Upper & p Value \\
\hline Age & 1.071 & 1.060 & 1.083 & $<0.001$ \\
Gender (M/F) & 1.463 & 1.007 & 2.126 & 0.046 \\
Chronic_disease & 0.487 & 0.330 & 0.719 & $<0.001$ \\
DM & 2.399 & 1.458 & 3.948 & 0.001 \\
Cardiac & 1.980 & 1.006 & 3.897 & 0.048 \\
Hospitalization & 1.205 & 0.853 & 1.704 & 0.290 \\
Surgery & 1.306 & 1.040 & 1.639 & 0.022 \\
Dental_procedure & 2.043 & 1.618 & 2.580 & $<0.001$ \\
Blood__transfusion & 1.295 & 0.904 & 1.853 & 0.158 \\
$\quad$ Barber & 1.156 & 0.793 & 1.686 & 0.451 \\
AntiBilharzial & 0.805 & 0.542 & 1.196 & 0.283 \\
\hline
\end{tabular}

$\chi^{2}$ test; M/F, male/female; $C I$ confidence level

\section{Prevalence of hepatitis E virus antibodies}

All $505 \mathrm{HCV}$ participants were tested for HEV IgM and IgG. IgM was negative for all, but IgG was positive in $71.4 \%$ of the chronic hepatitis cases and $96.1 \%$ of those with advanced liver disease (201 cirrhosis and 3 HCC). Positive HEV IgG was significantly higher among patients with advanced liver disease $(p<0.001)$ (Table 5).

\section{Incidence of HCV}

A year after the initial survey, a re-evaluation of the previously HCV negative individuals was performed. Out of the 1543 HCV negative villagers, 153 were lost to follow-up, and 1390 villagers were screened again. Forty-seven had a positive HCV antibody test and were tested for HCV RNA. Thirty-eight percent of those undergoing a second screening $(18 / 47)$ proved to have anti-HCV antibodies yet undetectable HCV RNA. A positive PCR for HCV RNA confirmed active infection in 29 villagers, placing the yearly incidence of new $\mathrm{HCV}$ infections in the village at $2.09 \%$ (20.9 cases per 1000 persons per year) (Fig. 1).

The newly infected were $12(41.4 \%)$ males and $17(58.6 \%)$ females; their mean age was $45.9 \pm 11.1$ years. They were questioned regarding any risk factors they had been exposed to during the year between both screenings. The highest risk factor for acquiring the infection was surgical operations for $12 / 29$ (41.45) followed by dental procedures for $10 / 29$ $(34.5 \%)$ (Table 6).

\section{Discussion}

The overall prevalence of the positive HCV population of the rural Nagreej village, Basyoun, Gharbia Governorate was $24.22 \%$, which is higher than the national Egyptian prevalence rate for $\mathrm{HCV}$ antibody positivity previously estimated at 10\% (Egypt Health Issues Survey 2015). This can be explained by the fact that the national prevalence rate takes into consideration the entirety of Egypt, including low and high prevalence areas combined. Living in a rural area is one of the risk factors for $\mathrm{HCV}$ in Egypt as the prevalence is higher than in urban areas (Strickland et al. 2002). Several surveys have been carried out in Egypt to determine this high prevalence of HCV in rural areas (Egypt Health Issues Survey 2015). AbdelWahab et al. (1994) recorded a prevalence of $18.1 \%$ for rural village residents in Menoufia. A study by Kamel et al. (1994) in Sada, Kafr El Sheikh, recorded a prevalence of $15.9 \%$ among village residents.

Prevalence rates were higher with increasing age which is in accordance with studies by El Damaty et al. (2007) and both the EDHS surveys in 2008 (El-Zanaty and Way 2009) and 2015 (Egypt Health Issues Survey 2015). This may be 
Table 5 Seroprevalence of HEV $\mathrm{IgG}$ in $\mathrm{HCV}$-infected patients

\begin{tabular}{|c|c|c|c|c|c|}
\hline \multirow{4}{*}{$\begin{array}{l}\text { Parameters } \\
\text { Age in years } \\
\text { Mean } \pm \text { SD }\end{array}$} & \multicolumn{4}{|c|}{ HCV-infected patients $(n=505)$} & \multirow{4}{*}{$\begin{array}{l}p \text { Value } \\
<0.001 * \$\end{array}$} \\
\hline & \multicolumn{2}{|c|}{$\mathrm{CHC}(n=301)$} & \multicolumn{2}{|c|}{ Advanced liver disease $^{\mathrm{a}}(n=204)$} & \\
\hline & & $\%$ & & $\%$ & \\
\hline & \multicolumn{2}{|c|}{$43.80 \pm 9.53$} & \multicolumn{2}{|l|}{$56.21 \pm 8.36$} & \\
\hline \multicolumn{6}{|l|}{ Gender } \\
\hline Male & 179 & 59.5 & 109 & 53.4 & \multirow[t]{2}{*}{$0.405^{\#}$} \\
\hline Female & 122 & 40.5 & 95 & 46.6 & \\
\hline \multicolumn{6}{|l|}{ HEV IgG } \\
\hline Positive & 215 & 71.4 & 196 & 96.1 & \multirow[t]{2}{*}{$<0.001^{* \#}$} \\
\hline Negative & 86 & 28.6 & 8 & 3.9 & \\
\hline
\end{tabular}

attributed to increased exposure to surgery, blood or blood product transfusions, and increased healthcare facility utilization as well as being included in the antischistosomal campaigns in the 1960s and 1970s. This elderly cohort with high $\mathrm{HCV}$ prevalence may play a considerable role in the continuing transmission of HCV in Egypt.

The higher HCV infection in males is in agreement with a study on 1000 participants from Kafr El Sheikh Governorate where $19.72 \%$ of males were seropositive, while only $9.12 \%$ of female participants were seropositive (Boghdady et al. 2014).

In the current study, a history of surgery was the highest on the list of risk factors, followed by dental procedures, hospitalization, blood transfusion, and a history of antischistosomal treatment, but use of contaminated needles, tattooing, and drug abuse were recorded as low risk factors in $\mathrm{HCV}$ transmission.

These risk factors are similar to those found by Strickland et al. (2002) which proved that parenteral therapy for schistosomiasis, past history of blood transfusions, previous surgical operations, and dental procedures are important risk factors for HCV transmission in Egypt. The high association with blood transfusion could be due to its occurrences in the past before screening of blood and blood donors. Tawk et al. (2005) stated that prior to enforcement of HCV screening of blood, transfusion recipients had a three times higher risk of infection than non-transfused individuals.

There is a decrease in the percentage of $\mathrm{HCV}$-infected cases with a history of antischistosomal treatment $(8.12 \%)$ in the present study than in the 2002 study by Strickland et al. $(65.9 \%)$. This is as expected due to the passage of time between the studies.

Mohlman et al. (2015) reported that those born in the 1950s were subject to the highest life time risk for acquiring $\mathrm{HCV}$ infection in the form of antischistosomal injections, frequent therapeutic injections, and blood transfusion $(22.7 \%, 34.8 \%$, and $22.4 \%$, respectively).

In our study, it is noted that the highest prevalence was among housewives, workers, and farmers. This is in contrast with the study of Boghdady et al. (2014) who found a high sero-prevalence in fishermen and farmers among all candidates' ages, but among those older than 40 years of age, the highest sero-prevalence was among medical staff, followed by office employees and lastly by manual laborers, and in those younger than 40 years, the highest sero-prevalence was in students and employees and the lowest prevalence in workers and housewives.

In the current study, the presence of diabetes was significantly higher in HCV positive villagers than in HCV negative ones.

Glucose abnormalities among HCV-infected patients in absence of cirrhosis are three times more prevalent than individuals with no such infection, revealing HCV infection as an independent determinant of glucose abnormalities (Lecube et al. 2004). A 9-year study proved that among adults aged 44-65 with a high diabetic risk, those infected with HCV were liable to develop type 2 diabetes 11 times more than their uninfected peers. The conclusion was that among diabetes susceptible adults, infection with hepatitis $\mathrm{C}$ poses a significant risk for its development (Mehta et al. 2003).

This is explained by the direct inhibition affected by the viral proteins on insulin signaling leading to insulin resistance (IR), which leads to acceleration of fibrosis, ultimately leading to development of cirrhosis and hepatocellular carcinoma (HCC) (Knobler and Malnick 2016).

There was a significantly elevated presence of cardiac disease among HCV positive villagers in the current study, but no such difference regarding the presence of hypertension.

Butt et al. (2009) found that individuals with HCV were significantly more liable to develop coronary artery disease and hypertension, compared with those free of infection, even following adjustment for known cardiac disease risks. A 


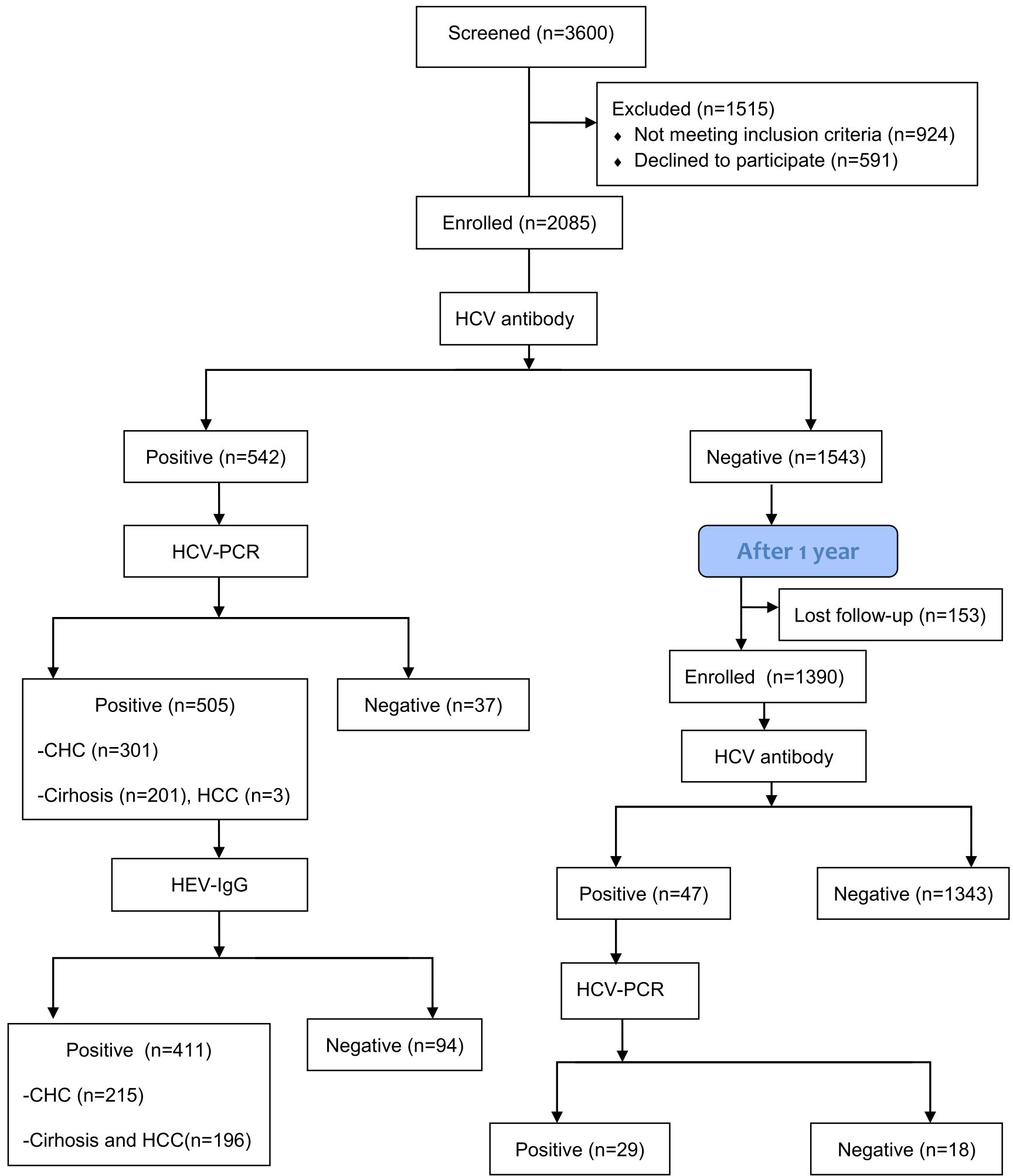

Fig. 1 Study analysis population. CHC, chronic hepatitis C; HCC, hepatocellular carcinoma; HCV, hepatitis C virus; HEV, hepatitis E virus; $n$, number of patients; PC, polymerase chain reaction

complex equilibrium between pro-inflammatory and antiinflammatory cytokines directs triggering, development, and rupture of atherosclerotic plaques (Hansson and Libby 2006). The levels of inflammatory markers have been found to be higher among those infected with HCV (Rios-Olivares et al. 2006).

One year after the first survey at Nagreej, 29 of $1390 \mathrm{HCV}$ negative villagers had become infected by the virus, putting 
Table 6 Risk factors for new hepatitis C infection

\begin{tabular}{|c|c|c|}
\hline \multirow[t]{2}{*}{ Medical history } & \multicolumn{2}{|c|}{ New hepatitis C infection $(n=29)$} \\
\hline & $n$ & $\%$ \\
\hline $\begin{array}{l}\text { Age in years } \\
\text { Mean } \pm \text { SD } \\
\text { Gender }\end{array}$ & $45.79 \pm 11.18$ & \\
\hline Male & 12 & 41.4 \\
\hline Female & 17 & 58.6 \\
\hline \multicolumn{3}{|c|}{ Hospital admission } \\
\hline Negative & 27 & 93.1 \\
\hline Positive & 2 & 6.9 \\
\hline \multicolumn{3}{|l|}{ Surgical history } \\
\hline Negative & 17 & 58.6 \\
\hline Positive & 12 & 41.4 \\
\hline \multicolumn{3}{|c|}{ Dental procedures } \\
\hline Negative & 19 & 65.5 \\
\hline Positive & 10 & 34.5 \\
\hline \multicolumn{3}{|l|}{ Blood transfusion } \\
\hline Negative & 26 & 89.7 \\
\hline Positive & 3 & 10.3 \\
\hline \multicolumn{3}{|c|}{ Use of contaminated needles, tattooing, and drug abuse } \\
\hline Negative & 29 & 100 \\
\hline Positive & 0 & 0 \\
\hline
\end{tabular}

the annual incidence of new HCV infections in the village at $2.09 \%$ (20.9 cases per 1000 persons per year).

A previous study of HCV incidence in Egypt by Mohamed et al. (2005) revealed an incidence of 6.8/1000 person-years (PY) among villagers in the Nile Delta and 0.8/1000 PY in a village of the Upper Egypt region.

In a 4-year population-based cohort study of HCV negative Egyptian villagers, twenty-five participants seroconverted; the incidence rate recorded was 2.4/1000 PY (Mostafa et al. 2010).

A history of blood transfusion during the year before new infection was unexpected as screening of blood bags and blood donors is currently meticulously implemented. Tawk et al. (2005) have also reported this, stating that even though blood screening for HCV is currently implemented, and has almost completely eliminated HCV from the blood supply, the association of HCV infection with blood transfusion is still ongoing. Their hypothesis was that other significant nosocomial risks must be associated with the clinical situations where patients received blood.

At the second screening, 18/47 villagers (38\%) tested positive for anti-HCV antibodies but had no detectable HCV RNA. This may be due to a spontaneously resolved acute $\mathrm{HCV}$ infection or a false-positive screening test.

Among the $\mathrm{HCV}$-infected villagers, $\mathrm{HEV} \mathrm{IgG} \mathrm{was} \mathrm{found} \mathrm{to}$ be positive in $71.4 \%$ of the chronic hepatitis patients and $96.1 \%$ of the advanced liver disease patients with cirrhosis and HCC pointing to a possible relationship between HEV and HCV and an effect of HEV on progression to late stage liver disease.

In the present study, all HEV antibodies in HCV-infected villagers were of the IgG and not of the IgM type. The possible explanation of this finding is that the presence of anti-HEV IgM signals a recent infection that would be of too short a duration to allow for it to play a role in cirrhosis or tumor development, whereas the presence of anti-HEV IgG indicates an older infection allowing for progression to cirrhosis and also tumor development.

The presence of anti-HEV IgM and/or anti-HEV IgG has been recorded previously in hepatitis $\mathrm{B}$ or $\mathrm{C}$ infected persons in comparison with healthy ones (Hamid et al. 2002). In Egypt, El Sayed and Othman (2011) reported a high prevalence of anti-HEV IgG among chronic liver disease Egyptian patients $(30 \%)$ and in those with hepatocellular carcinoma (13\%).

A recent study also found a high sero-prevalence (30\%) of $\mathrm{HEV}$ in chronic hepatitis $\mathrm{C}$ patients. As in the present study, the presence of anti-HEV IgG was significantly increased in cases of notable hepatic fibrosis equal to or above grade F2 (Mellgrena et al. 2017).

Among patients from the Cameroon with hepatocellular carcinoma, presence of $\operatorname{IgG}$ antibodies to hepatitis E was much higher than in chronic liver disease patients without HCC (41.8\% vs $12.6 \%$ ), suggesting either that hepatic cancers render patients more liable to $\mathrm{HEV}$ infection or that the virus may accelerate the development of malignancy in the liver (Amougou Atsama et al. 2017).

The high prevalence of CLD may be connected with flaws in the mucosal barrier of the gut, leading to viral translocation (Krain et al. 2014). The high HEV sero-prevalence among $\mathrm{HCV}$-infected individuals could be explained by the common routes of transmission. Some studies have reported the presence of HEV RNA in blood and blood products as well as incidences where recipients required the infection following transfusion (Huzly et al. 2014). In the study by Mellgrena et al. (2017), the highest anti-HEV IgG sero-prevalence (48\%) was found among patients that proved to have been infected with hepatitis $\mathrm{C}$ by means of blood transfusion, increasing the probability that HEV may be acquired by repeated transfusion.

Hepatitis E super-infection in chronic hepatic disease is presumed to cause a decline of liver functions, decompensation, and higher mortality rates (Ramachandran et al. 2004). The infection appears to contribute to worsening of hepatic inflammation and severity of HBV or HCV infection (Jahromi and Pourahmad 2013). In the same manner, it may hasten the progression to HCC. HEV has been identified as the sole cause of $\mathrm{HCC}$ in an immune-compromised patient (Borentain et al. 2018).

On the other hand, Samala et al. (2016) in the USA did not recognize the same effect of hepatitis $\mathrm{E}$ on patients with $\mathrm{HCV}$ related CLD. 


\section{Limitations}

The principal limitation of our study is that we did not measure HEV RNA and therefore cannot evaluate the effect of the viral load on the deterioration of chronic HCV liver disease. Another limitation was the lack of a control group regarding risk factors for follow-up incident cases.

\section{Conclusion}

$\mathrm{HCV}$ infection continues to be highly prevalent in Egypt, particularly among the elderly. The annual incidence in a small Nile Delta village is $2.086 \%$. Advanced liver disease patients and those with hepatocellular carcinoma in Egypt are more likely to have antibodies to HEV than their healthy counterparts. HCV-HEV co-infection or super infection may lead to a worse prognosis among Egyptians with chronic liver disease.

\section{Recommendations}

Further studies are needed to estimate the national Egyptian $\mathrm{HCV}$ incidence. Larger cohorts are needed to evaluate the effect of HEV/HCV co-infection and super-infection. Testing of HCV-infected patients for HEV super- or coinfection should be encouraged to determine those more liable to hepatic deterioration and $\mathrm{HCC}$ development.

Authors' contributions All the authors participated sufficiently in the work and approved the final version of the manuscript.

\section{Compliance with ethical standards}

The study protocol conforms to the ethical guidelines of the 1975 Declaration of Helsinki as reflected in a prior approval by the institution's human research committee on 5/9/2014 (code approval number: 2748/9/ 14). An informed consent was signed by all research participants, and the privacy of participants and confidentiality of the data was put into consideration.

Conflict of interest The authors declare that they have no conflict of interest.

\section{References}

Abdel-Wahab MF, Zakaria S, Kamel M et al (1994) High seroprevalence of hepatitis C infection among risk groups in Egypt. Am J Trop Med Hyg 51:563-567

Ahmed OA, Kaisar HH, Badawi R, Hawash N, Samir H, Shabana SST, Fouad MHA, Rizk F, Khodeir SA, Abd-Elsalam S (2018) Efficacy and safety of sofosbuvir-ledipasvir for treatment of a cohort of Egyptian patients with chronic hepatitis C genotype 4 infection. Infect Drug Resist 11:295-298
Amougou Atsama M, Atangana PJA, Noah Noah D, Moundipa PF, Pineau P, Njouom R (2017) Hepatitis E virus infection as a promoting factor for hepatocellular carcinoma in Cameroon: preliminary observations. Int J Infect Dis 64:4-8

Boghdady IM, ElKafrawy NA, Shoaib AA et al (2014) Seroprevalence and risk factors of hepatitis $\mathrm{C}$ virus infection among population in Kafr El Sheikh Governorate. Menoufia Med J 27:686-690

Borentain P, Colson P, Bolon E et al (2018) Hepatocellular carcinoma complicating hepatitis E virus-related cirrhosis. Hepatology 67(NO. 1)

Butt AA, Xiaoqiang W, Budoff M, Leaf D, Kuller LH, Justice AC (2009) Hepatitis $\mathrm{C}$ virus infection and the risk of coronary disease. Clin Infect Dis 49(2):225-232

Deeks ED (2015) COBAS® AmpliPrep/COBAS ${ }^{\circledR}$ Taqman® ${ }^{\circledR} \mathrm{HCV}$ quantitative test, version 2.0: an in vitro test for hepatitis $C$ virus RNA quantification. Mol Diagn Ther 19:1-7

Egypt Health Issues Survey (2015) Ministry of health and population [Egypt], El-Zanaty and associates [Egypt], and ICF International. 2015. Cairo, Egypt and Rockville, Maryland, USA: Ministry of Health and Population and ICF International

El Damaty SI, Hassan SK, Mohamed MK et al (2007) Surveillance system for HCV infection: testing a model based on blood banks. J Egypt Public Health Assoc 82:451-471

El Sayed ZM, Othman W (2011) Role of hepatitis E infection in acute on chronic liver failure in Egyptian patients. Liver Int 31:1001-1005

El-Zanaty F, Way A (2009) Egypt demographic and health survey 2008. Cairo, Egypt: Ministry of Health, El-Zanaty and associates, and macro international, 431

Frank C, Mohamed MK, Strickland GT, Lavanchy D, Arthur RR, Magder LS, Khoby TE, Abdel-Wahab Y, Ohn ESA, Anwar W, Sallam I (2000) The role of parenteral antischistosomal therapy in the spread of hepatitis C virus in Egypt. Lancet 355(9207):887-891

Hamid SS, Atiq M, Shehzad F, Yasmeen A, Nissa T, Salam A, Siddiqui A, Jafri W (2002) Hepatitis E virus superinfection in patients with chronic liver disease. Hepatology 36:474-478

Hansson GK, Libby P (2006) The immune response in atherosclerosis: a double- edged sword. Nat Rev Immunol 6:508-519

Huzly D, Umhau M, Bettinger D et al (2014) Transfusion-transmitted hepatitis e in Germany, 2013. Euro Surveill 19(21):20812

Jahromi AS, Pourahmad M (2013) Hepatitis E virus and serum level aminotransferases in blood donors. Rep Biochem Mol Biol 2:48-51

Kamel MA, Miller FD, El Masry AG et al (1994) The epidemiology of Schistosoma mansoni, hepatitis B and hepatitis C infection in Egypt. Ann Trop Med Parasitol 88:501-509

Knobler H, Malnick S (2016) Hepatitis C and insulin action: an intimate relationship. World J Hepatol 8(2):131-138

Krain LJ, Nelson KE, Labrique AB (2014) (2014): Host immune status and response to hepatitis E virus infection. Clin Microbiol Rev 27: $139-165$

Lecube A, Hernández C, Genescà J et al (2004) High prevalence of glucose abnormalities in patients with hepatitis $\mathrm{C}$ virus infection: a multivariate analysis considering the liver injury. Diabetes Care 27: $1171-1175$

Mehta SH, Brancati FL, Strathdee SA, Pankow JS, Netski D, Coresh J, Szklo M, Thomas DL (2003) Hepatitis C virus infection and incident type 2 diabetes. Hepatology 38:50-56

Mellgrena A, Karlssona M, Karlssonb M et al (2017) High seroprevalence against hepatitis $\mathrm{E}$ virus in patients with chronic hepatitis $\mathrm{C}$ virus infection. J Clin Virol 88:39-45

Mohamed MK, Abdel-Hamid M, Mikhail NN et al (2005) Intrafamilial transmission of hepatitis C in Egypt. Hepatology 42:683-687

Mohlman MK, Saleh DA, Ezzat S et al (2015) Viral transmission risk factors in an Egyptian population with high hepatitis $\mathrm{C}$ prevalence. BMC Public Health 15:1030 
Mostafa A, Taylor SM, el-Daly M et al (2010) Is the hepatitis C virus epidemic over in Egypt? Incidence and risk factors of new hepatitis $\mathrm{C}$ virus infections. Liver Int 30:560-566

Ramachandran J, Eapen CE, Kang G et al (2004) Hepatitis, superinfection produces severe decompensation in patients with chronic liver disease. J Gastroenterol Hepatol 19:134-138

Rein DB, Stevens GA, Theaker J, Wittenborn JS, Wiersma ST (2012) The global burden of hepatitis E virus genotypes 1 and 2 in 2005 . Hepatology 55:988-997

Rios-Olivares E, Vila LM, Reyes JC et al (2006) Impaired cytokine production and suppressed lymphocyte proliferation activity in HCV-infected cocaine and heroin ("speedball”) users. Drug Alcohol Depend 85:236-243

Samala N, Wright EC, Buckler AG, Vargas V, Shetty K, Reddy KR, Lucey MR, Alter HJ, Hoofnagle JH, Ghany MG (2016) Hepatitis virus does not contribute to hepatic decompensation among patients with advanced chronic hepatitis C. Clin Gastroenterol Hepatol 14: 896-902

Strickland GT, Elhefni H, Salman T et al (2002) Role of hepatitis C infection in chronic liver disease in Egypt. Am J Trop Med Hyg 67(4):436-442

Tawk HM, Vickery K, Bisset L, Lo SK, Cossart YE, the Infection in Endoscopy Study Group (2005) The significance of transfusion in the past as a risk for current hepatitis $\mathrm{B}$ and hepatitis $\mathrm{C}$ infection: a study in endoscopy patients. Transfusion 45(5):807-813

Publisher's note Springer Nature remains neutral with regard to jurisdictional claims in published maps and institutional affiliations. 